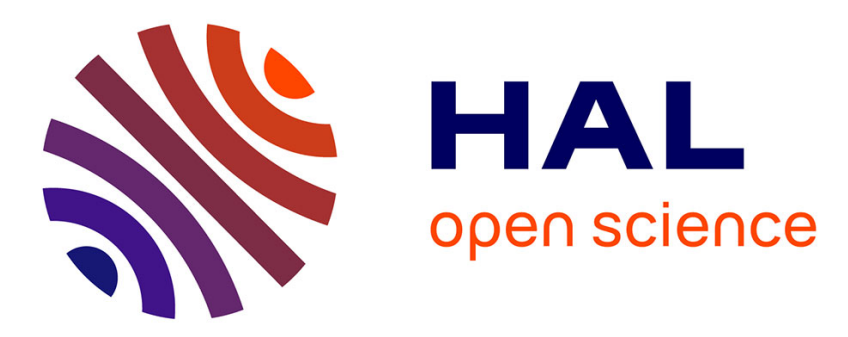

\title{
Student's Acceptance of Learning Management Systems: A Case Study of the National Open University of Nigeria
}

\author{
Mohammed N. Yakubu, Muhammadou Kah, Salihu I. Dasuki
}

\section{To cite this version:}

Mohammed N. Yakubu, Muhammadou Kah, Salihu I. Dasuki. Student's Acceptance of Learning Management Systems: A Case Study of the National Open University of Nigeria. 1st International Conference on Sustainable ICT, Education, and Learning (SUZA), Apr 2019, Zanzibar, Tanzania. pp.245-255, 10.1007/978-3-030-28764-1_27. hal-02515748

\section{HAL Id: hal-02515748 \\ https://hal.inria.fr/hal-02515748}

Submitted on 23 Mar 2020

HAL is a multi-disciplinary open access archive for the deposit and dissemination of scientific research documents, whether they are published or not. The documents may come from teaching and research institutions in France or abroad, or from public or private research centers.
L'archive ouverte pluridisciplinaire $\mathbf{H A L}$, est destinée au dépôt et à la diffusion de documents scientifiques de niveau recherche, publiés ou non, émanant des établissements d'enseignement et de recherche français ou étrangers, des laboratoires publics ou privés. 


\title{
Student's Acceptance of Learning Management Systems: A Case Study of The National Open University of Nigeria
}

\author{
Mohammed N Yakubu ${ }^{1[0000-0002-5952-228 X]}$ Muhammadou M. O. Kah ${ }^{1}$ and Salihu I \\ Dasuki ${ }^{2[0000-0002-4130-8509]}$ \\ ${ }^{1}$ American University of Nigeria, Yola 640101, Nigeria \\ ${ }^{2}$ The University of Sheffield, Sheffield, S10 2TN, UK \\ yakubu.m@aun.edu.ng, mkah@aun.edu.ng, s.dasuki@sheffield.ac.uk
}

\begin{abstract}
This research examines the key factors that influence the acceptance of learning management systems (LMS') by students of the National Open University of Nigeria (NOUN). To achieve this, the constructs from previous studies on eLearning acceptance were adopted to develop a conceptual model. Based on the model, structural equation modeling (SEM) was applied to the data obtained from 384 students. The results indicated that instructor quality is a determinant of learning value and perceived usefulness; system quality is a determinant of perceived ease of use and perceived usefulness; perceived ease of use, facilitating conditions, learning value, and perceived use-fullness are significant predictors of behavioral intention. Also, facilitating conditions and behavioral intention significantly predicted the usage of the LMS by the students. Contrary to expectations, the following relationships were found to be non-significant: course quality to learning value and perceived usefulness; and social influence on behavioral intentions. The conceptual model used in this study attains an acceptable fit and explains its variance for $67 \%$ of the student sample. This study contributes to the formulation of policies and guidelines to improve student's acceptance of learning management systems in developing countries. The paper also adds to the existing body of technology acceptance literature.
\end{abstract}

Keywords: eLearning acceptance, Nigerian universities, students, LMS.

\section{Introduction}

Universities in developed countries have embraced eLearning and research has shown that eLearning can be beneficial to both students and instructors [1]. Developing countries, on the other hand, have to overcome certain factors in order to implement eLearning. Social factors [2], cultural factors [3] and organizational factors are some of the considerations that must be taken into account with regards to the student's acceptance of eLearning in developing countries.

There are only a few studies that have been carried out by applying different theories and models in order to understand the factors that influence Nigerian students to 
accept an LMS. Theories like the unified theory of acceptance and use of technology (UTAUT) [4, 5] and the DeLone and McLean IS success model [6] has been used in order to explain Nigerian students' acceptance of LMS'.

While these models are quite good at explaining user's acceptance of using technology, they do not capture certain factors that are specific to eLearning systems, specifically LMS'. For instance, the influence of the instructor or the design and content of the course are some factors that have been proven to significantly influence student's acceptance of eLearning systems [7].

The main aim of this study is to investigate the student's acceptance of an LMS (NOUN iLearn platform) by developing and testing a conceptual model. The constructs that make up the model is derived from IS literature that has investigated the acceptance of eLearning technologies by students.

The conceptual model as well as the associating hypotheses are shown in fig. 1 . The constructs, as well as their relationships, is based on validated theories such as TAM [8], UTAUT [9, 10] and the DeLone and McLean IS success model [11]. Other constructs such as course quality [7], instructor quality [7, 12] and learning value [13] were added to the model as they have been used and validated in prior studies in the acceptance of eLearning systems

\section{$2 \quad$ Literature Review}

\subsection{The context of the Study}

The National Open University of Nigeria (NOUN) is Nigeria's largest tertiary institution with over 500,000 students, as of 2017 [14], distributed across 77 study centers and touching all the local government areas(LGAs) and states in the six geopolitical zones of Nigeria. NOUN is the first open and distance learning institution in West Africa and was fully established in 2011. NOUN caters for students at different levels (undergraduate and postgraduate) and for the majority of the students, there are no traditional face-to-face lectures. Students learn using the NOUN iLearn platform, an online portal which provides functionalities such as class discussions, assignments and quizzes, eBooks and other digitized learning materials, networking and collaboration tools and communication to NOUN facilitators where students can ask questions pertaining to their courses. Examinations are administered in the NOUN study centers spread across the country and are either computer-based or pen-onpaper depending on the level of study and the type of course taken. Other facilities to aid the students are the eLibrary which provides access to books, journals, and other educative resources.

\subsection{Acceptance of Technology}

The acceptance of technology has been well studied and applied to various types of information systems such as online/mobile banking applications [15, 16, 17, 18], ecommerce applications [19-21] and eLearning [5, 6, 12]. Also, several theories have been postulated in a bid to explain why users accept different types of technologies. 
With regards to the use of technology, two (2) approaches have been identified [22]. The first is the user satisfaction approach which focuses on the information and system properties; an example is the DeLone and McLean information systems (IS) success model [23-24]. The second approach is the technology acceptance model which is based on an individual's perception of using the technology; examples include TAM (technology acceptance model) [25] and UTAUT (unified theory of acceptance and use of technology) [26]. This study employs the constructs from 3 models, TAM, UTAUT and the DeLone and McLean IS success model. TAM and UTAUT fall into the technology acceptance models and are 2 of the most popular information systems (IS) theories used in research.

TAM [25] is based on the Theory of Reasoned Action (TRA) [27] which is derived from the social psychology domain. TAM was adapted into the information systems field and postulates that perceived usefulness (PU) and perceived ease of use (PEOU) of a system influences an individual's intention to use the system. This, in turn, translates to the actual use of the system. TAM can be extended by the use of external variables which act as determinants to PU or/and PEOU. In the context of eLearning acceptance, TAM has been used extensively by researchers, see [28-31].

The second theory employed in the conceptual model is the unified theory of acceptance and use of technology (UTAUT and UTAUT2) [9-10]. UTAUT [9] was developed by the consolidation of 8 models (including TAM) which resulted in 4 key constructs as determinants of behavioral intentions. The constructs are performance expectancy, effort expectancy, social influence, and facilitating conditions. Similar to TAM, behavioral intentions translate to usage behavior. UTAUT has been used in the investigation of student's acceptance of eLearning systems such as Canvas LMS [5] and Moodle LMS by postgraduate students [32]. UTAUT 2 [10] builds on the original UTAUT model by adding 3 constructs: hedonic motivation, habit and price value. These constructs were added to address the evolution of information systems over time which now caters for consumers. Similarly, UTAUT 2 has been validated in the context of eLearning [33].

The third model used in the research framework is the DeLone and McLean IS success model [23-24]. The model tries to define IS success via the use of IS dimensions. These dimensions are information quality, system quality, service quality, user satisfaction, and net benefits. Thus an information system is evaluated on the quality attributes of the system (information, system and service quality) which influence the user satisfaction and the intention to use the system. The DeLone and McLean IS success model has also been used in the study of eLearning acceptance by students [6, 12, 34].

The 3 theories were selected as they have all been empirically tested in the domain of eLearning systems acceptance. TAM was chosen as it allows the use of extending the model by the addition of external variables. The external variables added to the conceptual model are derived from the DeLone and McLean IS success model. While UTAUT was included, as it was the best model for explaining usage intention with a variance of $70 \%$ [26]. The next section discusses the research model and justification of the constructs used in the model. 


\section{Research Framework}

The research model is shown in figure 1. As mentioned in the previous section, 3 models were used to develop the research model. Each of the constructs in the research model is defined and the associated relationships explained below:

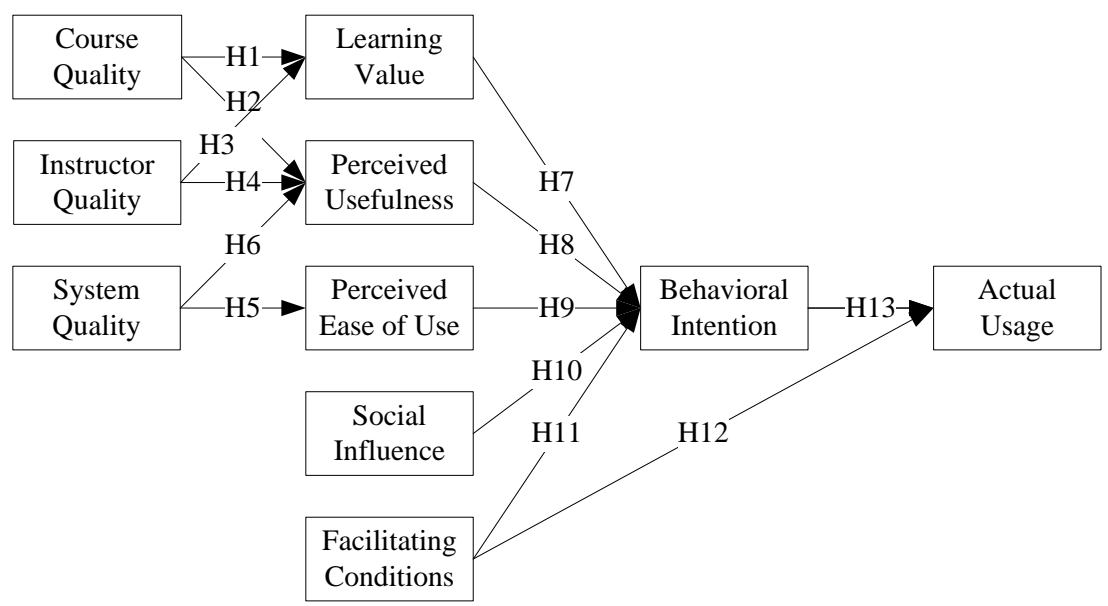

Fig. 1. Research Model

Course Quality (CQ): Several authors have replaced the information quality construct, derived from the DeLone and McLean IS success model, with course quality (course design and course content) in the context of eLearning systems [7, 3537]. For the purpose of this study, CQ is a measure of the students' perception of the content and design of the course on the learning platform and as a result, it is expected to:

- H1: Course quality will significantly influence learning value.

- H2: Course quality will significantly influence perceived usefulness.

Instructor Quality (IQ): Instructors play an important role in the acceptance of eLearning systems by students [7]. Similar to prior research by [7] and [12] this study measures the instructor's influence based on the instructor's responses and attitude towards the students and the style of instruction while using the LMS. Similar to prior research, [7, 12, 34], it is expected that:

- H3: Instructor quality will significantly influence learning value.

- H4: Instructor quality will significantly influence perceived usefulness.

System Quality: Adapted from the DeLone and McLean IS success model, SQ is a measure of the features the LMS, these include ease of use, functionality, reliability, and efficiency. Cheng [7] has shown that SQ has a significant influence on perceived usefulness and perceived ease of use, thus: 
- H5: System quality will significantly influence perceived ease of use.

- H6: System quality will significantly influence perceived usefulness.

Learning Value (LV): Learning value as a construct was used to replace the Price Value construct from UTAUT 2 [10] by Ain et al. [33]. There is no monetary value attributed to the use of LMS' by students, instead, the value obtained by students is time and effort invested in using the LMS. The value expected by this investment has been proven to be a determinant of eLearning systems [33], hence:

- H7: Learning value will significantly influence behavioral intention

Perceived Usefulness (PU): "Perceived usefulness is defined as the degree to which a person believes that using a particular system would enhance his/her job performance”, [8]. PU is expected to influence a student's behavioral intention to use the LMS based on the TAM model, therefore:

- H8: Perceived usefulness will significantly influence behavioral intention

Perceived Ease of Use (PEOU): PEOU is derived from TAM, it is defined "as the degree to which a person believes that using a particular system would be free of physical and mental effort”, [8]. PEOU is expected to influence students behavioral intention to use the LMS, thus we propose:

- H9: Perceived ease of use will significantly influence behavioral intention

Social Influence (SI): SI "is defined as the degree to which an individual perceives that important others believe he or she should use the new system” [9]. SI captures the influence of people important to the student to use the LMS. These important others include the university administration and classmates. Based on the UTAUT model, SI significantly influences behavioral intention, thus:

- H10: Social influence will significantly influence behavioral intention

Facilitating Conditions (FC): FC is derived from the UTAUT model; it is a collection of the resources (support and technologies) that facilitate the use of the LMS by the NOUN students. In UTAUT, FC is a predictor of both behavioral intention as well as actual usage of the system, therefore:

- H11: Facilitating conditions will significantly influence behavioral intention

- H12: Facilitating conditions will significantly influence the actual usage.

Behavioral Intentions (BI): BI captures the student's intention to use the LMS for their studies. Similar to all 3 underlying theories employed by this study, it is expected that:

- H13: Behavioral intention will significantly influence use

Actual Usage (AU): AU is a measure of the student's actions and activities while using the LMS. The research model (fig. 1) indicates that FC and BI are the only direct determinants of AU; this relationship is similar to the UTAUT 2 model. 


\section{$4 \quad$ Method}

All 3 models used in this research were quantitative in nature, thus a paper-based survey was used to collect the data required for this study. 500 questionnaires were distributed with the assistance of 2 administrative staff of the National Open University and 384 valid responses were returned. The administrative staffs were trained on handling the consent forms and questionnaires and helped to distribute them to students. The students were required to submit the completed survey in a ballot type box to ensure anonymity. Also, approval from our institutional review board was sought to ensure that human subject rules and regulations are adhered to.

The instrument used in the study was divided into 2 sections. Section 1 captured demographic information about the participants such as age, gender, level of study (undergraduate or postgraduate), the length of using the LMS and whether prior training was given before using the LMS. Section 2 includes items for the 10 constructs which were derived from the models used to develop the research model. A 5-point Likert scale was used for responses where 1 represented strongly agree and 5 represented strongly disagree. The survey was developed and administered in the English language, which is a requirement for admission into the university. Also, a pilot study was carried out to review errors and rephrase questions that might seem ambiguous.

The data were examined using a two-step approach [38] and structural equation modeling (SEM) using SPSS and Amos was used to analyze the data.

\section{$5 \quad$ Findings}

Table 1 summarizes the demographic information of the respondents. 63.8\% (245) were male and $36.2 \%$ (139) were female. The majority of the students (76.6\%) were over 30 years of age and $58.9 \%$ were at the postgraduate level. Also, most of the respondents had used the NOUN iLearn portal for over 2 years and $68.2 \%$ of the students had no prior training on using the portal.

Table 2 shows a summary of the descriptive analysis of the respondent's responses in the second section of the survey. Most mean values are between 1 and 2 indicating that the responses were positive and the standard deviation were all under 1.401 showing that the data is close to the mean.

Internal reliability was established using the Cronbach's alpha for each construct. Table 2 shows that the Cronbach's alpha values are acceptable as they are all above 0.7 .

Table 3 summarizes the model fit indices and shows that the data for both the measurement and structural model are a good fit, as all the indices measured were within the recommended values as recommended by [39, 40].

Convergent validity (CV) and divergent validity (DV) tests were carried out to evaluate the construct items measured in this study. DV was established as MSV values (maximum shared variance) and the ASV values (average shared variance) are 
less than the corresponding average variance extracted (AVE) values [40] as shown in table 4.

Table 1. Demographic information of respondents $(n=384)$

\begin{tabular}{llcc}
\hline Demographic & Characteristic & Frequency & Percent \\
\hline \multirow{3}{*}{ Age } & $17-21$ & 3 & .8 \\
& $21-30$ & 87 & 22.7 \\
\multirow{3}{*}{ Gender } & Over 30 & 294 & 76.6 \\
& Male & 245 & 63.8 \\
Level of Study & Female & 139 & 36.2 \\
& Undergraduate & 158 & 41.1 \\
Length of & Postgraduate & 226 & 58.9 \\
Usage & Less than 1 year & 64 & 16.7 \\
& 1-2 Years & 91 & 23.7 \\
Training & Over 2 years & 229 & 59.6 \\
& Yes & 122 & 31.8 \\
\hline
\end{tabular}

Table 2. Descriptive analysis of the constructs

\begin{tabular}{ccccc}
\hline $\begin{array}{c}\text { Const } \\
\text { ruct }\end{array}$ & No of Items & SD & Mean & Cronbach's Alpha \\
\hline AU & 2 & 0.617 & 1.397 & 0.808 \\
IQ & 3 & 1.151 & 2.273 & 0.946 \\
CQ & 4 & 1.401 & 3.107 & 0.860 \\
SQ & 4 & 0.887 & 1.693 & 0.870 \\
BI & 4 & 0.843 & 1.602 & 0.868 \\
FC & 4 & 0.683 & 1.679 & 0.784 \\
PEOU & 4 & 0.733 & 1.527 & 0.817 \\
LV & 3 & 0.708 & 1.641 & 0.783 \\
PU & 3 & 0.578 & 1.424 & 0.832 \\
SI & 2 & 0.752 & 2.24 & 0.707 \\
\hline
\end{tabular}

Similarly, CV is established by the composite reliability values being over 0.7 , the AVE values over 0.5 and AVE values were found to be less than the corresponding CR values [40]. 
Table 3. Model Fit Indices

CFI: Comparative fit index, GFI: Goodness-of-fit index, AGFI: Adjusted goodness-of-fit; RMSEA: Root mean square error of approximation; RMSR: Root mean square residuals; NFI: Normed fit index.

\begin{tabular}{cccc}
\hline Fit Index & Recommended Value & $\begin{array}{c}\text { Measurement } \\
\text { Model }\end{array}$ & Structural Model \\
\hline CFI & $>0.90$ & 0.946 & 0.932 \\
GFI & $>0.90$ & 0.912 & 0.911 \\
AGFI & $>0.80$ & 0.816 & 0.806 \\
RMSEA & $<0.08$ & 0.061 & 0.06 \\
RMSR & $<0.10$ & 0.063 & 0.065 \\
NFI & $>0.90$ & 0.927 & 0.924 \\
\hline
\end{tabular}

Confirmatory factor analysis (CFA) was applied to the data in order to evaluate the path strength and significance between the constructs of the research model. Table 4 shows the results from the CFA. Of the 14 hypotheses tested, 4 of the relationships were found to be non-significant.

Table 4. Construct Reliability

\begin{tabular}{ccccc}
\hline Constructs & CR & AVE & MSV & ASV \\
\hline AU & 0.842 & 0.735 & 0.194 & 0.070 \\
IQ & 0.949 & 0.862 & 0.280 & 0.090 \\
CQ & 0.862 & 0.610 & 0.280 & 0.070 \\
SQ & 0.873 & 0.635 & 0.462 & 0.100 \\
BI & 0.873 & 0.633 & 0.301 & 0.120 \\
FC & 0.798 & 0.503 & 0.194 & 0.060 \\
PEOU & 0.821 & 0.534 & 0.462 & 0.110 \\
LV & 0.810 & 0.598 & 0.289 & 0.100 \\
PU & 0.840 & 0.637 & 0.289 & 0.120 \\
SI & 0.763 & 0.644 & 0.008 & 0.000 \\
\hline
\end{tabular}

\section{Discussion and Conclusion}

This study applies a developed model in order to understand the factors that influence students of the National Open University of Nigeria (NOUN) to use the web based learning management system. The findings from this study can be used as a guide for the administration of NOUN on how best to improve the NOUN iLearn portal which currently caters for the educational needs of over 500,000 students, as of 2017 [14], 
who are distributed across 77 study centers and touching all the local government areas and states in the six geopolitical zones of Nigeria.

Table 5. Relationship between the Constructs

$($ Estimate $=$ standardized regression coefficient $;$ S.E $=$ standardized error $; P=$ significant level)

\begin{tabular}{ccccccc}
\hline $\begin{array}{c}\text { Hypoth } \\
\text { esis }\end{array}$ & Path & & Estimate & P & $\begin{array}{c}\text { Significan } \\
\text { ce }\end{array}$ \\
\hline H1 & CQ & $\rightarrow$ & LV & -0.034 & 0.279 & NS \\
H2 & CQ & $\rightarrow$ & PU & -0.028 & 0.224 & NS \\
H3 & IQ & $\rightarrow$ & LV & 0.218 & $* * *$ & S \\
H4 & IQ & $\rightarrow$ & PU & 0.157 & $* * *$ & S \\
H5 & SQ & $\rightarrow$ & PEOU & 0.468 & $* * *$ & S \\
H6 & SQ & $\rightarrow$ & PU & 0.081 & 0.002 & S \\
H7 & LV & $\rightarrow$ & BI & 0.246 & $* * *$ & S \\
H8 & PU & $\rightarrow$ & BI & 0.326 & $* * *$ & S \\
H9 & PEOU & $\rightarrow$ & BI & 0.671 & $* * *$ & S \\
H10 & SI & $\rightarrow$ & BI & 0.055 & 0.505 & NS \\
H11 & FC & $\rightarrow$ & BI & 0.172 & 0.018 & S \\
H12 & FC & $\rightarrow$ & AU & 0.426 & $* * *$ & S \\
H13 & BI & $\rightarrow$ & AU & 0.195 & $* * *$ & S \\
\hline
\end{tabular}

Table 5 indicates that out of the 13 hypotheses tested, 10 were supported while 3 were rejected. There was no support that the social influence of important others to the students was responsible for the usage of the NOUN iLearn portal. This finding is consistent with a similar study on student's acceptance of an LMS by [5]. The reason for this could be due to the fact that students interact mainly with the system as opposed to traditional schools where the interaction is mainly face-to-face with peers, instructors, and administrators.

Information and system quality (IQ and SQ) were found to be determinants of the usefulness (PU) of the system, this means that the higher the quality of the instructors and the iLearn portal play the more useful the portal is to the students. The quality of the instructors also positively influences the student's perceived learning value. Unfortunately the course quality had no significant relationship with PU or LV, implying that the student's perception of the course resources and design do not add value to their learning process or the usefulness of the portal and this is corroborated by CQ having the highest mean value (3.107) which is a neutral response by the students.

Similar to prior studies, a positive and significant relationship was found between the system quality and PEOU [7] also between the system quality and PU [7, 12], the 
students, therefore, believe that the usefulness and ease of using the system is based on the quality of the system.

In this study, LV, PU, PEOU, and FC were all discovered to positively influence $\mathrm{BI}$; hence students' intention to use the system is influenced by the learning value, the usefulness, and ease of use of the system as well as the facilitating conditions.

The final relationship shows that behavioral intention of the students translates to the actual usage of the NOUN iLearn portal.

This study investigates the various factors responsible for the acceptance of the NOUN iLearn portal by students of NOUN. The results show that more effort is required in developing the course content and structure as it had no effect on the learning value or the usefulness of the system on the students. The findings also indicate that the quality of the system has the highest influence on the ease of using the system, while the ease of using the system is the most influential factor on the students' intention to use the system.

\section{$7 \quad$ Limitations And Further Research}

There are several limitations to this study which can be addressed in future research. Age and gender of the respondents are partial to over 30 years old and male respectively. Because of how NOUN is structured, most of the students are categorized as "mature students" who are currently employed and seeking to develop themselves professionally. Therefore the findings from this study might not necessarily be applied to younger students. Future works could use age and gender as moderators to examine the different effects on the factors used in this study. As this study is quantitative in nature, speculations can only be made on the results; further in-depth investigations (qualitative approach) would be required to strengthen the reasons why the Nigerian students use an LMS.

As the instructors are key users of the portal and considered to be influential in the use of the portal by the students, their perception on the use of the NOUN iLearn portal should be considered in future research. Finally, the scope of the research can be increased to other institutions using different types of LMS'.

\section{References}

1. Garrison, D. R.: E-learning in the 21st century: A framework for research and practice. Routledge, (2011).

2. Schepers, J., Wetzels, M.: A meta-analysis of the technology acceptance model: Investigating subjective norm and moderation effects. Information \& Management 44(1), 90-103 (2007).

3. Masoumi, D.: Quality in E-learning within a cultural context. (2010).

4. Olatunbosun, O., Olusoga, F. A., Samuel, O. A.: Adoption of eLearning technology in Nigeria tertiary institution of learning. British Journal of Applied Science \& Technology 10(2), 1-15 (2015). 
5. Yakubu, M. N., Dasuki, S. I.: Factors Affecting the Adoption of eLearning Technologies among Higher Education Students in Nigeria: A Structural Equation Modeling Approach. Information Development, (2018).

6. Yakubu, M. N., Dasuki, S. I.: Assessing eLearning Systems Success in Nigeria: An Application of the DeLone and McLean Information Systems Success Model. Journal of Information Technology Education: Research 17, 183-203 (2018).

7. Cheng, Y. M.: Effects of quality antecedents on e-learning acceptance. Internet Research 22(3), 361-390 (2012).

8. Davis, F.: Perceived USefulness, Perceived Ease of Use, and Acceptance of Information Technology. MIS Quarterly, 319-340 (1989).

9. Venkatesh, V., Morris, M. G., Davis, G. B., Davis, F. D.: User acceptance of information technology: Toward a unified view. MIS Quarterly 27(3), 425-478 (2003).

10. Venkatesh, V., Thong, J. Y., Xu, X.: Consumer Acceptance and Use of Information Technology: Extending the Unified Theory of Acceptance and Use of Technology. MIS Quarterly 36(1), 157-178 (2012).

11. DeLone, W. H., McLean, E. R.: The DeLone and McLean model of information systems success: a ten-year update. Journal of management information systems 19(4), 9-30 (2003).

12. Lwoga, E.: Critical success factors for adoption of web-based learning management systems in Tanzania. International Journal of Education and Development using ICT 10(1), (2014).

13. Ain, N., Kaur, K., Waheed, M.: The influence of learning value on learning management system use: An extension of UTAUT2. Information Development 32(5), 1306-1321 (2016).

14. Premium Times Nigeria. Student population in Nigerian Open University hits 254,000, https://www.premiumtimesng.com/news/top-news/223277-student-population-nigerianopen-university-hits-254000.html, last accessed 2018/09/28.

15. Aboelmaged, M., Gebba, T. R.: Mobile banking adoption: an examination of technology acceptance model and theory of planned behavior. International Journal of Business Research and Development. (2013).

16. Aderonke, A. A.: An empirical investigation of the level of users' acceptance of e-banking in Nigeria. Journal of Internet Banking and Commerce 15(1), 1 (2010).

17. Alalwan, A. A., Dwivedi, Y. K., Rana, N. P., Lal, B., Williams, M. D.: Consumer adoption of Internet banking in Jordan: Examining the role of hedonic motivation, habit, self-efficacy, and trust. Journal of Financial Services Marketing 20(2), 145-157 (2015).

18. Alsajjan, B., Dennis, C.: The impact of trust on acceptance of online banking. (2006).

19. Lallmahamood, M.: An Examination of Individualâ s Perceived Security and Privacy of the Internet in Malaysia and the Influence of This on Their Intention to Use E-Commerce: Using An Extension of the Technology Acceptance Model. The Journal of Internet Banking and Commerce. (2015).

20. Li, W., \& Yang, C.: Study of Factors Affecting Tourists’ Adoption Behavior of Mobile Ecommerce. Journal of Residuals Science \& Technology 13(7), (2016).

21. Wixom, B. H., Todd, P. A.: A theoretical Integration of User Satisfaction and Technology Acceptance. Information Systems Research 16(1), 85-102 (2005).

22. DeLone, W. H., McLean, E. R.: Measuring e-commerce success: Applying the DeLone \& McLean information systems success model. International Journal of electronic commerce 9(1), 31-47 (2004).

23. DeLone, W. H., McLean, E. R.: Information systems success: The quest for the dependent variable. Information systems research 3(1), 60-95 (1992). 
24. DeLone, W. H., McLean, E. R.: The DeLone and McLean model of information systems success: a ten-year update. Journal of management information systems 19(4), 9-30 (2003).

25. Davis, F.: Perceived USefulness, Perceived Ease of Use, and Acceptance of Information Technology. MIS Quarterly, 319-340 (1989).

26. Venkatesh, V., Davis, M. M., Davis, F. D.: User acceptance of information technology: Toward a unified view. MIS Quarterly, 425-478 (2003).

27. Fishbein, M., Ajzen, I.: Belief, attitude, intention, and behavior : An introduction to theory and research. Addison-Wesley Pub. Co, Ontario (1975).

28. Alharbi, S., Drew, S.: Using the technology acceptance model in understanding academics' behavioral intention to use learning management systems. International Journal of Advanced Computer Science and Applications 5(1), 143-155 (2014).

29. Lee, Y.-H., Hsieh, Y.-C., Chen, Y.-H.: An investigation of employees' use of e-learning systems: applying the technology acceptance model. Behaviour \& Information Technology, 173-189 (2013).

30. Adewole-Odeshi, E.: Attitude of students towards e-learning in south-west Nigerian universities: An application of technology acceptance model. (2014).

31. Park, S. Y.: An analysis of the technology acceptance model in understanding university students' behavioral intention to use e-learning. Journal of Educational Technology \& Society 12(3), 150 (2009).

32. Raman, A., Don, Y., Khalid, R., Rizuan, M.: Usage of learning management system (Moodle) among postgraduate students: UTAUT model. Asian Social Science. (2014).

33. Ain, N., Kaur, K., Waheed, M.: The influence of learning value on learning management system use: An extension of UTAUT2. Information Development 32(5), 1306-1321 (2016).

34. Lin, H. F.: Measuring Online Learning Systems Success: Applying the Updated DeLone and McLean Model. Cyberpsychology \& Behavior 10(6), 817-820 (2007).

35. Lee, Y. C.: An empirical investigation into factors influencing the adoption of an elearning system. Online information review 30(5), 517-541 (2006).

36. Lee, B. C., Yoon, J. O., Lee, I.: Learners' acceptance of e-learning in South Korea: Theories and results. Computers \& Education 53(4), 1320-1329 (2009).

37. Choi, D. H., Kim, J., Kim, S. H.: ERP training with a web-based electronic learning system: the flow theory perspective. International Journal of Human-Computer Studies 65(3), 223-243 (2007).

38. Anderson, J. C., Gerbing, D. W.: Structural equation modeling in practice: A review and recommended two-step approach. Psychological Bulletin 103(3), 411 (1988).

39. Kline, R. B.: Principles and Practice of Structural Equation Modeling. Guilford publications, New York, NY (2015).

40. Hair, J. F., Black, W. C., Babin, B. J., Anderson, R. E., Tatham, R. L.: Multivariate data analysis. (Vol. 5). Prentice Hall, Upper Saddle River, NJ (2010). 